\title{
Preliminary results from EMERSITO, a rapid response network for site-effect studies
}

\author{
Paola Bordoni ${ }^{1}{ }^{\star}$, Riccardo M. Azzara $^{1}$, Fabrizio Cara ${ }^{1}$, Rocco Cogliano ${ }^{1}$, Giovanna Cultrera ${ }^{1}$, \\ Giuseppe Di Giulio ${ }^{1}$, Antonio Fodarella ${ }^{1}$, Giuliano Milana ${ }^{1}$, Stefania Pucillo ${ }^{1}$, Gaetano Riccio ${ }^{1}$, \\ Antonio Rovelli ${ }^{1}$, Paolo Augliera ${ }^{2}$, Lucia Luzi ${ }^{2}$, Sara Lovati ${ }^{2}$, Marco Massa ${ }^{2}$, \\ Francesca Pacor ${ }^{2}$, Rodolfo Puglia ${ }^{2}$, Gabriele Ameri ${ }^{2}$
}

${ }^{1}$ Istituto Nazionale di Geofisica e Vulcanologia, Sezione Roma 1, Roma, Italy
${ }^{2}$ Istituto Nazionale di Geofisica e Vulcanologia, Sezione di Milano/Pavia, Milano, Italy

\section{Article history}

Received July 24, 2012; accepted August 13, 2012.

Subject classification:

Spectral ratios, Emilia 2012 earthquake, Rapid response seismic network, Site effect, Seismic array, Strong motions.

\section{Introduction}

On May 20, 2012, at 02:03 UTC, a $M_{L} 5.9$ reverse-fault earthquake occurred in the Emilia-Romagna region, northern Italy, at a hypocentral depth of $6.3 \mathrm{~km}$ (http: / / iside.rm. ingv.it/), close to the cities of Modena and Ferrara in the plain of the Po River. The epicenter was near the village of Finale Emilia where macroseismic intensity was assessed at 7 EMS98 [Tertulliani et al. 2012, this issue], while the closest accelerometric station, MRN, located less than $20 \mathrm{~km}$ west-ward at Mirandola (Figure 1) recorded peaks of ground accelerations of about $300 \mathrm{~cm} / \mathrm{s}^{2}$ (www.protezionecivile.gov.it/resources/ cms/documents/Report_DPC_1_Emilia_EQSd.pdf).

The mainshock triggered liquefaction phenomena a few kilometers eastwards of the epicenter, around the village of San Carlo. On the same day, two other shocks of $M_{L} 5.1$ followed (02:07, 13:18 GMT; http:/ / iside.rm.ingv.it/). On May 29,2012 , at 07:00 UTC another $M_{L} 5.8$ earthquake hit the region (http://iside.rm.ingv.it/), with the epicenter close to the village of Mirandola (Figure 1). Three other strong aftershocks occurred afterwards, of $\mathrm{M}_{\mathrm{L}} 5.3$ (May 29, at 10:55), $M_{L} 5.2$ (May 29, at 11:00) and $M_{L} 5.1$ (June 3, at 19:20). For a detailed description of the seismic sequence, see Moretti et al. [2012], Scognamiglio et al. [2012], and Massa et al. [2012], in this issue. The Emilia seismic sequence resulted in $25 \mathrm{ca}-$ sualties, several of whom were among the workers in the many factories that collapsed during working hours, and there was extensive damage to monuments, public buildings, industrial sites, and private homes.

The Po Plain region that was struck by the 2012 Emilia seismic sequence is a very large E-W trending syntectonic alluvial basin, which covers about $45,000 \mathrm{~km}^{2}$. It is surrounded by the Alps to the north and the Apennines to the south, and it is filled with Plio-Pleistocene terrigenous sediments and
Holocene deposits, with depths varying from a few hundred meters up to several kilometers. The epicentral area was located south of the Po River, corresponding to the active front of the northern Apennines thrust belt (north-vergence), which is composed of buried folds and thrust faults that locally produce structural highs (Figure 1), and are known as Pieghe Emiliane and Ferraresi [Pieri and Groppi 1981]. The top of this limestone and marl bedrock rises to ca. $100 \mathrm{~m}$ from the surface and has been derived locally from borehole logs. The seismic response of this ca. 150-m-deep soft cover was investigated using weak-motion events and microtremors recorded in a borehole by Margheriti et al. [2000].

The occurrence of the May 2012 seismic sequence made it possible to study the seismic response under near-field conditions. These studies are aimed at providing tools to reduce the impact of future earthquakes on the local communities. In addition to the amplification due to one-dimensional (1D) resonance, it is well known that seismic responses of deep sedimentary basins are affected by $2 \mathrm{D}$ and 3D effects (e.g., wave diffraction, conversion at the basin edges, trapping and focusing of energy within the soil volume). Evidence of basin-induced surface waves and edge effects have been observed in many basins worldwide; e.g., the Osaka basin in Japan [e.g., Kawase 1996, Pitarka et al. 1998], various southern California basins [Graves et al. 1998, Day et al. 2008], and the Parkway basin in New Zealand [Chávez-García et al. 1999]. In Italy, good examples of site amplification in alluvial basins can be found for the Gubbio, Città di Castello, L'Aquila and Fucino basins [ Bordoni et al. 2003, Bindi et al. 2009, Cara et al. 2011, Milana et al. 2011].

Therefore, the day after the mainshock, the INGV rapidresponse network for site effects, called EMERSITO, planned the experiments presented in this report. EMERSITO put together independent research groups from several territorial 

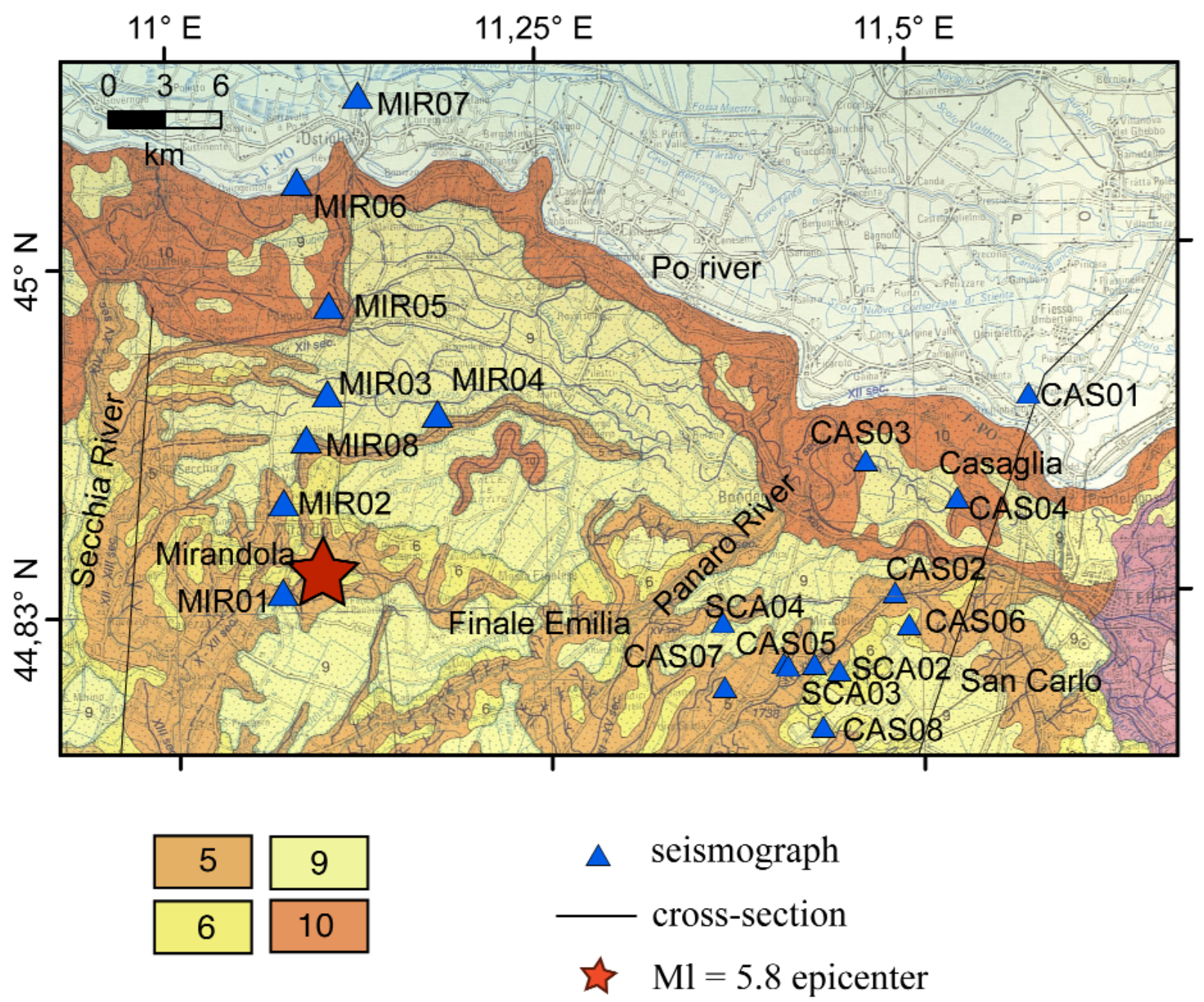

Figure 1. Geological map (redrawn from Regione Emilia Romagna 1999) showing the sites investigated and the traces of the two geological crosssections of Figure 2. The red star indicates the epicenter of the May 29 event $\left(M_{L}\right.$ 5.8). (5) Medium and fine sand, channel and proximal levee deposit; (6) Sandy silt, distal levee deposit; (9) Silty clay, back-swamp deposits; (10) Sand, meander belt deposit.

centers of the Istituto Nazionale di Geofisica e Vulcanologia (INGV; National Institute of Geophysics and Volcanology) who agree to collaborate spontaneously and on the basis of a data archiving and sharing policy. They then deployed their seismic equipment in the epicentral area, building on the experience of the 2009 L'Aquila earthquake [Di Giulio et al. 2011, Margheriti et al. 2011, Milana et al. 2011]. The deployment was planned also in collaboration with the geological survey of the Regione Emilia Romagna (Servizio Geologico e Sismico e dei Suoli) and the University of Modena, as well as being in the framework of SISMIKO [Moretti et al. 2012]. As a result of this effort, since May 22, three linear arrays have been deployed (Figure 1), with a total of 22 sites instrumented, 16 of them equipped with both velocimeters and accelerometers. These arrays recorded most of the aftershock sequence, including the $\mathrm{M}_{\mathrm{W}}$ 5.8 May 29, 2012, 07:00 earthquake. The continuous recordings will be archived into the EIDA database (http:/ / eida.rm.ingv.it/) under restricted access.

The aim of this report is to describe the experiments performed by the EMERSITO team, as well as the main features of the recorded earthquakes. A preliminary insight in the site response of the investigated area within the context of the geological structure of the Po Plain is also given.

\section{Near-surface geology}

The epicentral area is characterized by a flat morphology with geomorphic features typical of the area that rise locally from the plain. There are river levees, anthropic fillings, and abandoned river channels of the tributaries of the Po River, which drain the northern Apennines (Figure 1). The superficial geology of the study area is dominated by paleo-river-bed sediments (mainly sand, sand-silty and silty-clay) of the Secchia, Panaro and Reno Rivers. Within these sediments locally it is possible to find some confined aquifers, whereas in the deep sedimentary cover there are some aquifers of regional importance [Regione Emilia Romagna ENI-AGIP 1998].

Most of the liquefaction effects occurred between Sant' Agostino and San Carlo, along a belt following the abandoned river bed of the Reno River (Emergeo: http:/ / terremoti. ingvit/it/ultimi-eventi / 842-terremoti-in-pianura-padanaemiliana.html and this issue; http: / / ambiente.regione.emiliaromagna.it/geologia/temi/sismica/liquefazione-gruppo-di- 

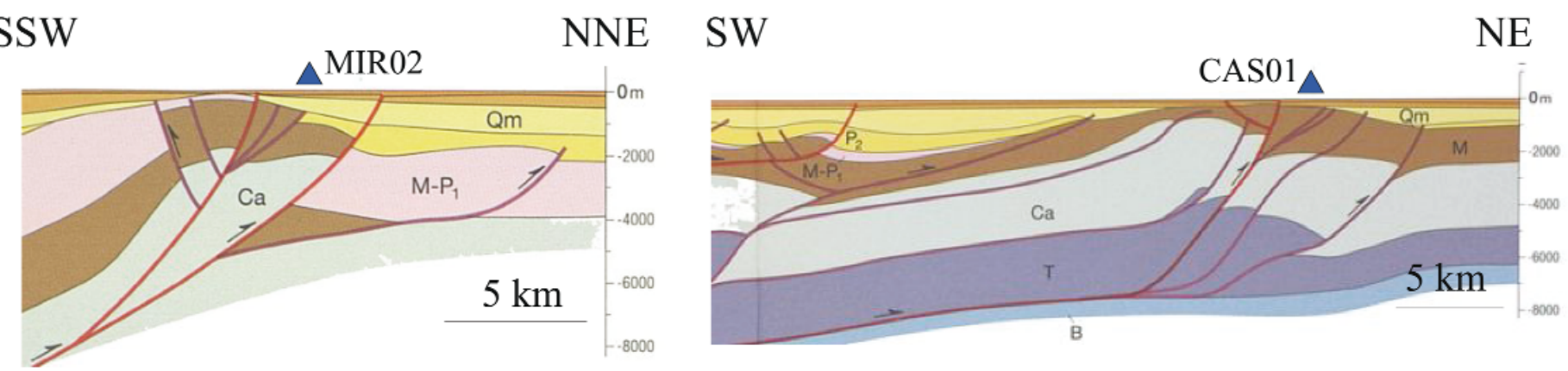

seismograph
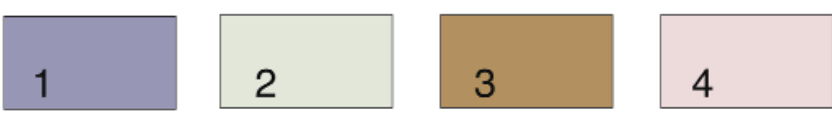

5

Figure 2. Geological cross-sections of Figure 2 (redrawn from Cerrina Feroni et al. [2002]) crossing the Mirandola structural high (left; MIR02) and the Casaglia structural high (right; CAS01). (1) Lower and medium Triassic; (2) Meso-Cenozoic carbonatic succession; (3) Miocene; (4) Late Messinian-Early Pliocene; (5) Late Pliocene to Holocene.

\begin{tabular}{|c|c|c|c|c|c|c|}
\hline Code & Site & $\begin{array}{c}\text { Latitude } \\
\left(^{\circ}\right)\end{array}$ & $\underset{\left({ }^{\circ}\right)}{\text { Longitude }}$ & 1 & 2 & $\begin{array}{l}\text { Recordings } \\
\text { from (2012) }\end{array}$ \\
\hline \multirow[t]{2}{*}{ CAS01 } & Occhiobello & 44.929280 & 11.577100 & & $\mathrm{X}$ & May 23 \\
\hline & & & & $\mathrm{X}$ & $\mathrm{X}$ & May 30 \\
\hline CAS02 & Vigarano Mainarda & 44.836032 & 11.483373 & $\mathrm{X}$ & $\mathrm{X}$ & May 23 \\
\hline \multirow[t]{2}{*}{ CAS03 } & Settepolesini, Bondeno & 44.899740 & 11.465930 & & $\mathrm{X}$ & May 23 \\
\hline & & & & $\mathrm{X}$ & $\mathrm{X}$ & May 30 \\
\hline CAS04 & Ca' Pontoni, Vigarano Mainarda & 44.880535 & 11.526858 & $\mathrm{X}$ & $\mathrm{X}$ & May 23 \\
\hline CAS05 & San Carlo, Sant'Agostino & 44.802222 & 11.409715 & $\mathrm{X}$ & $\mathrm{X}$ & May 24 \\
\hline CAS06 & Madonna dei Boschi, P. Renatico & 44.820308 & 11.491826 & $\mathrm{X}$ & $\mathrm{X}$ & May 24 \\
\hline \multirow[t]{2}{*}{ CAS07 } & Ceramiche Sant'Agostino & 44.792920 & 11.367070 & & $\mathrm{X}$ & May 23 \\
\hline & & & & $\mathrm{X}$ & $\mathrm{X}$ & May 29 \\
\hline \multirow[t]{2}{*}{ CAS08 } & Chiesa Nuova, P. Renatico & 44.772600 & 11.432190 & & $\mathrm{X}$ & May 22 \\
\hline & & & & $\mathrm{X}$ & $\mathrm{X}$ & May 29 \\
\hline MIR01 & Medolla & 44.844038 & 11.071097 & $\mathrm{X}$ & $\mathrm{X}$ & May 24 \\
\hline MIR02 & Mirandola & 44.886968 & 11.073191 & $\mathrm{X}$ & $\mathrm{X}$ & May 22 \\
\hline MIR03 & Azienda VILLA, Mirandola & 44.938401 & 11.104550 & $\mathrm{X}$ & $\mathrm{X}$ & May 23 \\
\hline MIR04 & Gavello, Mirandola & 44.927463 & 11.178325 & $\mathrm{x}$ & $\mathrm{x}$ & May 24 \\
\hline MIR05 & Villa Poma & 44.980808 & 11.107172 & $\mathrm{X}$ & $\mathrm{X}$ & May 23 \\
\hline MIR06 & Pieve di Coriano & 45.040113 & 11.087507 & $\mathrm{X}$ & $\mathrm{x}$ & May 23 \\
\hline MIR07 & sede Polizia Stradale, Ostiglia & 45.081006 & 11.130050 & $\mathrm{X}$ & $\mathrm{X}$ & May 23 \\
\hline MIR08 & Quarantoli, Mirandola & 44.916868 & 11.089485 & $\mathrm{x}$ & $\mathrm{x}$ & May 24 \\
\hline SCA01 & San Carlo, centro & 44.803500 & 11.407000 & & $\mathrm{X}$ & May 29 \\
\hline SCA02 & San Carlo, Via Riolo & 44.799750 & 11.443390 & & $\mathrm{X}$ & May 29 \\
\hline SCA03 & San Carlo, contrada San Pietro & 44.802970 & 11.427590 & & $\mathrm{X}$ & May 30 \\
\hline SCA04 & Casumaro, Via Gazzinella 8 & 44.823979 & 11.366673 & & $\mathrm{x}$ & May 30 \\
\hline SCA05 & Sant'Agostino,Via dei Frutteti & 44.809700 & 11.391680 & & $\mathrm{x}$ & June 9 \\
\hline SCA06 & Sant'Agostino, Via quattro torri & 44.812050 & 11.375010 & & $\mathrm{X}$ & June 9 \\
\hline
\end{tabular}

Table 1. The sites studied. 1, Episensor; 2, Lennartz Le3d-5s. 
lavoro). Recent, very detailed investigations performed by Regione Emilia Romagna (http: / / ambiente.regione.emiliaromagna.it/geologia/temi/sismica/liquefazione-gruppo-dilavoro) at San Carlo reconstructed a geological cross-section through the abandoned channel of the Reno River, where the most severe effects of the ground fracture and liquefaction occurred. In the first $20 \mathrm{~m}$ of subsoil, there were scattered lenses with confined aquifers formed by fine sands, mainly in sandy-silt and silty-sand complexes, which are supposed to have been responsible for the surface effects.

\section{The experiments}

The temporary stations were installed along two roughly N-S trending profiles (Figure 1), where geological cross-sections were already available (Figure 2). The purpose was to investigate, on the one hand, the geometry of the sedimentary cover, which appears to thicken moving away from the structural highs. On the other hand, the site selection was focused on studying the effects of the abandoned riverbeds, as well as on damage suffered by the local factories.
The eastern-most profile (the CAS array) cuts through the boreholes around the village of Casaglia, where the bottom of the Quaternary deposits has been reached at $140 \mathrm{~m}$ in depth. Seismic responses had been investigated by the evaluation of surface-to-downhole spectral ratios [Margheriti et al. 2000]. Unfortunately this borehole instrumentation was not operating during the seismic sequence. The CAS array consists of eight stations installed along a SW-NE direction. Four of the CAS array sites were equipped at the beginning with Reftek 72A three-channel digitizers coupled to Lennartz Le3d-5s seismometers. At the other sites, where Reftek R130 six-channel digitizers were available, Kinemetrics Episensor accelerometers were added (see Table 1). Station CAS5 is located at San Carlo village, where the most serious liquefaction phenomena and ground failure took place. From the May 29, 2012, the Reftek 72A was substituted with a Reftek 130 six-channel digitizer, and re-deployed along a third array of six stations across the San Carlo village (the SCA array) with E-W trending (Table 1).

The western-most profile (the MIR array) cuts through
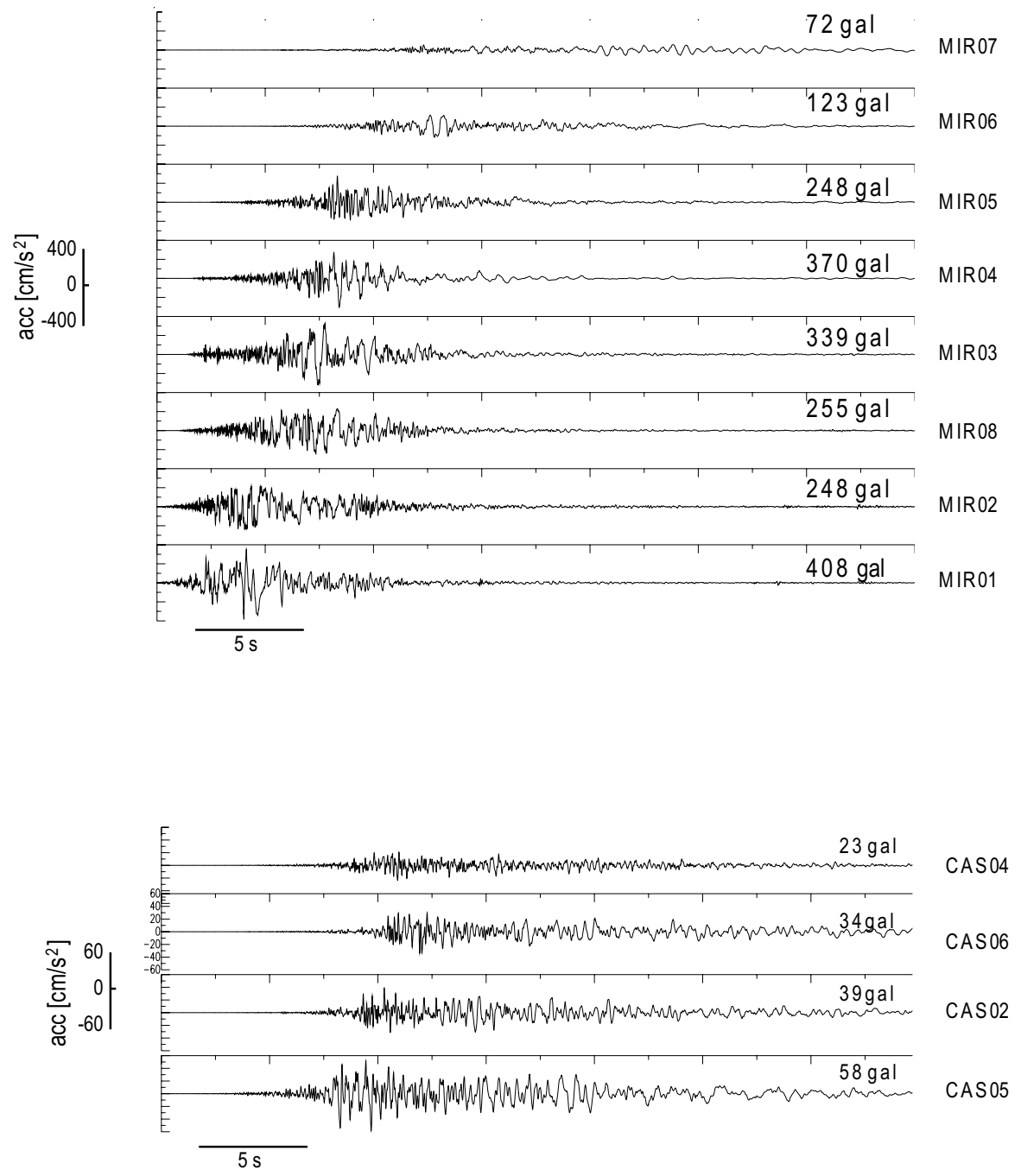

Figure 3. Waveforms of the north components of the ground acceleration recorded along the two arrays during the May 29 event. Top: the NS-oriented MIR array, on the western edge of the sequence area. Bottom: the NNE-SSW-oriented CAS array, on the eastern edge of the sequence area. Waveforms are arranged as increasing epicentral distances, with PGAs (gal) given. 


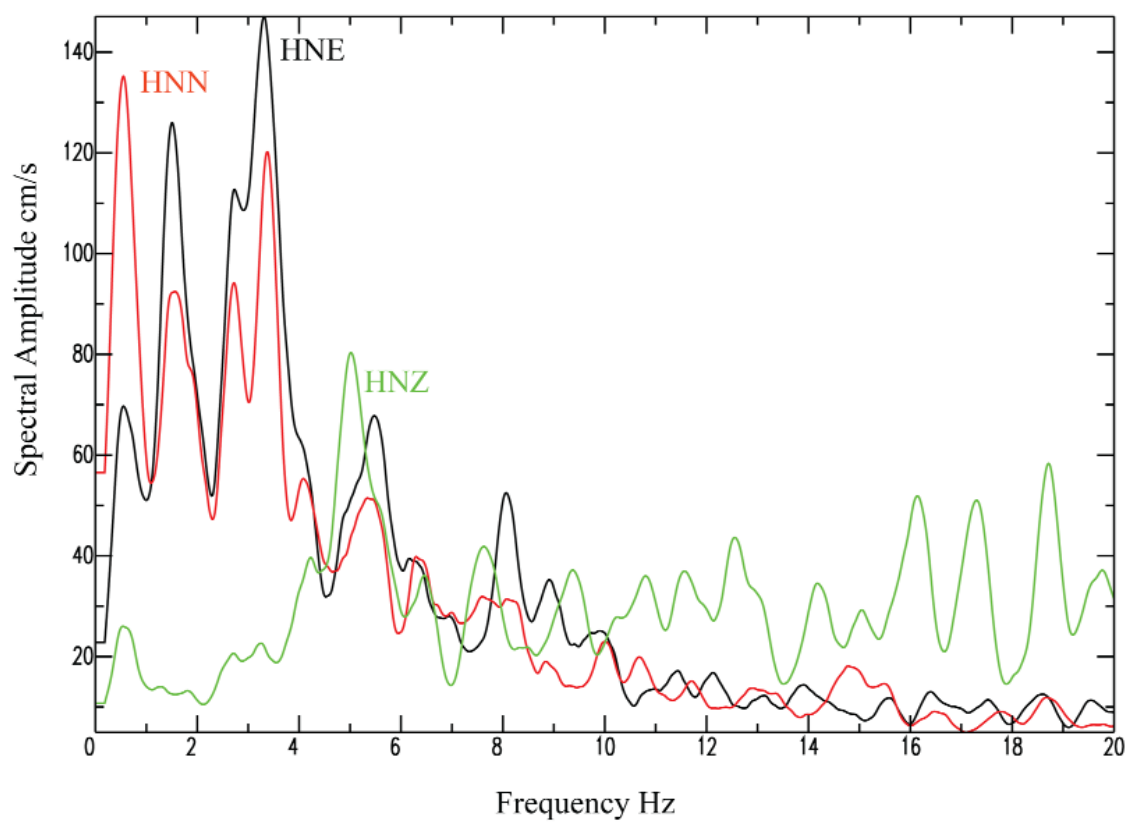

Figure 4. Fourier amplitude spectra of the three components of acceleration recorded at the MIR2 station during the earthquake of May 29. HNN, HNE and $\mathrm{HNZ}$ are respectively the NS, EW and UP component of acceleration.
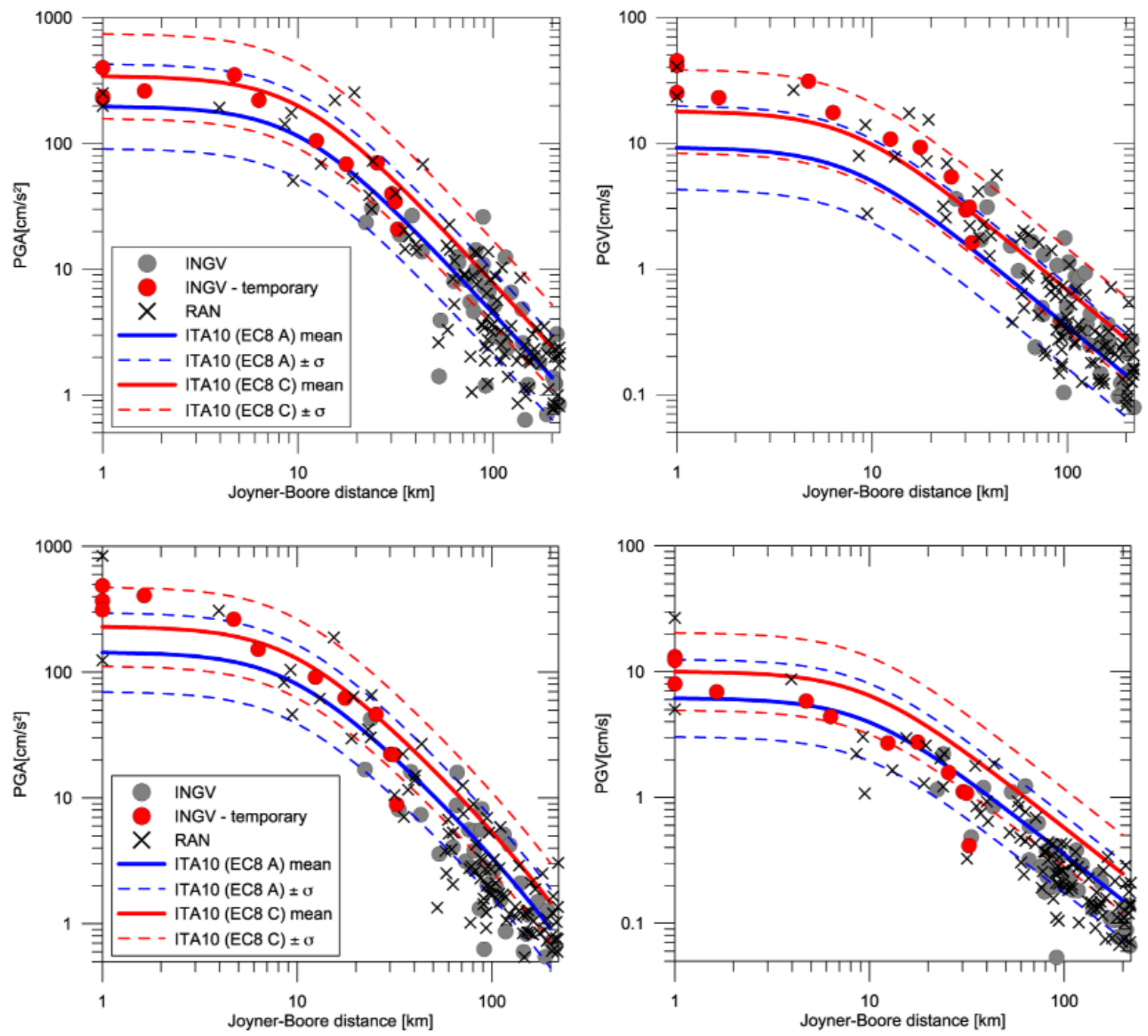

Figure 5. Comparisons between the predictions [Bindi et al. 2011] and the measurements of PGA (left) and PGV (right) for the geometric means of the horizontal components (top) and the vertical component (bottom) for the May 29 event. Red circle, peak values from transect stations; gray circles, peak values from INGV stations; black crosses, RAN stations. 
the Mirandola structural high, where a peak ground acceleration (PGA) of about $300 \mathrm{~cm} / \mathrm{s}^{2}$ was recorded at the MRN site during the mainshock (www.protezionecivile.gov.it/ resources/cms/documents/Report_DPC_1_Emilia_EQSd. pdf). The station is included in the permanent accelerometric network, RAN, that is operated by the Dipartimento di Protezione Civile Nazionale (DPC). The MIR array was composed of eight Quanterra330 six-channel digitizers connected to a Lennartz Le3d-5s velocimeter and a Kinemetrics Episensor distributed along a N-S trending profile.

\section{Results and discussion}

4.1. Time series features and comparisons with strong-motion prediction law

Figure 3 shows the NS horizontal components of the ground acceleration for the May 29, 2012, event $\left(\mathrm{M}_{\mathrm{L}}\right.$ 5.8) located at a hypocentral depth of ca. $10.2 \mathrm{~km}$, and with the epicenter close to MIR01. Whereas the P-waves first arrival is quite clear, the $S$-waves arrival is not easily detectable. The seismograms showed high complexity due to a considerable amount of elastic energy that was released as local surface waves, which increased in amplitude with increasing epicentral distance. These are the main features of the ground motion that were recorded. A fast decay of the amplitude with distance was also evident. For frequencies $>10 \mathrm{~Hz}$ (Figure 4), the vertical component has an amplitude that is higher than the horizontal components. Despite this difference in the frequency content, the PGAs for the horizontal and vertical components were similar.

At this stage, it is not possible to associate the features due to source, propagation, or site effects. In terms of horizontal displacement, the data recorded under near-source conditions showed peak displacements of the order of $20 \mathrm{~cm}$ to $30 \mathrm{~cm}$ at low frequency.

The strong motion records for the May 29, 2012, event were corrected with the procedure described by Pacor et al. [2011], and were filtered in the frequency band between $0.1 \mathrm{~Hz}$ and $40 \mathrm{~Hz}$. In Figure 5, the derived PGA and peak ground velocity (PGV) for the geometric means of the horizontal components and of the vertical component are compared to estimates from a ground-motion prediction equation assessed from the database of Italian earthquakes [Bindi et al. 2011] (ITA10) and with the other peak values observed by the INGV and RAN stations located in the distance range of $0 \mathrm{~km}$ to $200 \mathrm{~km}$.

The predictions are computed for the reverse fault and for sites A and C in the EC8 classification (EC8 class A: shearwave velocity averaged over the top $30 \mathrm{~m}$ of the soil profile, with Vs30 $>800 \mathrm{~m} / \mathrm{s}$; and EC 8 class C, with Vs30 $=180-360$ $\mathrm{m} / \mathrm{s})$. From the geological and geophysical information available, we attributed the sites monitored to site $\mathrm{C}$ in the EC8 classification. The distances from the fault were computed by defining fault geometry based on geological and focal mechanism data (Quick Regional Centroid Moment Tensor, http:/ / autorcmt.bo.ingv.it/quicks.html).

The mean predictions for C sites in the EC8 classification fit well with the observed PGAs for both components, except for very short distances $(<5 \mathrm{~km})$, where the vertical peak values tended to be larger than the ITA10 mean estimates. At distances shorter than $10 \mathrm{~km}$, the horizontal PGVs were within the median and the median plus one standard deviation estimates for $\mathrm{C}$ sites according to the EC8. Conversely, except for the near-fault peak values at Joyner-Boore distances [Joyner and Boore 1981], RJB $=1 \mathrm{~km}$, the ITA10 predictions for EC8 C sites overestimated the observed data for the vertical component, which decayed with distance following the mean curve for EC8 A sites.

These comparisons indicated that the ground motion from the May 29, 2012, event was characterized by larger low-frequency content in the horizontal components, with respect to the average trend expected for the Italian territory; this is probably related to the deep sediments of the Po Plain. The vertical components at short distances are more affected by high frequencies, and this was also clearly seen by a visual inspection of waveforms.

4.2. H/V spectral ratios from earthquake and noise measurements

Due to the large distance between the bedrock outcroppings and the studied area and to the lack of borehole instrumentation, we could not select a site to use as reference for computing standard spectral ratios for earthquakes [Borcherdt 1970]. Therefore, we computed the empirical transfer function using the horizontal-to-vertical $(\mathrm{H} / \mathrm{V})$ spectral ratio (HVSR) earthquakes after Lermo and ChavezGarcia [1993].

The HVSR was computed over 20 s of waveform, starting at the P-wave arrival and including $S$-waves as well as part of the early surface waves. The use of windows containing $\mathrm{P}$-waves, $\mathrm{S}$-waves and surface waves might violate the receiver function assumption of the vertical component being amplification free. However, due to the short epicentral distances, it is very difficult to split the P-wave and S-wave arrivals (the

\begin{tabular}{ccccc}
\hline $\begin{array}{c}\text { Origin time, UTC } \\
\text { (yyyy-mm-dd hh:mm:ss) }\end{array}$ & $\begin{array}{c}\text { Latitude } \\
\left({ }^{\circ}\right)\end{array}$ & $\begin{array}{c}\text { Longitude } \\
\left({ }^{\circ}\right)\end{array}$ & $\begin{array}{c}\text { Depth } \\
(\mathbf{k m})\end{array}$ & $\mathbf{M}$ \\
\hline 2012-05-25 10:31:23 & 44.861 & 11.258 & 6.1 & 3.9 \\
2012-05-29 07:00:03 & 44851 & 11.086 & 10.2 & 5.8 \\
2012-05-29 08:36:00 & 44.857 & 11.055 & 10.0 & 3.7 \\
2012-05-29 09:30:21 & 44.892 & 11.053 & 1.2 & 4.2 \\
$2012-05-29$ 10:55:57 & 44.888 & 11.008 & 6.8 & 5.3 \\
$2012-05-29 ~ 14: 39: 40$ & 44.882 & 11.068 & 20.6 & 3.9 \\
$2012-06-06 ~ 04: 08: 31$ & 44.434 & 12.354 & 25.6 & 4.5 \\
\hline
\end{tabular}

Table 2. Hypocentral parameters of the earthquakes selected. 

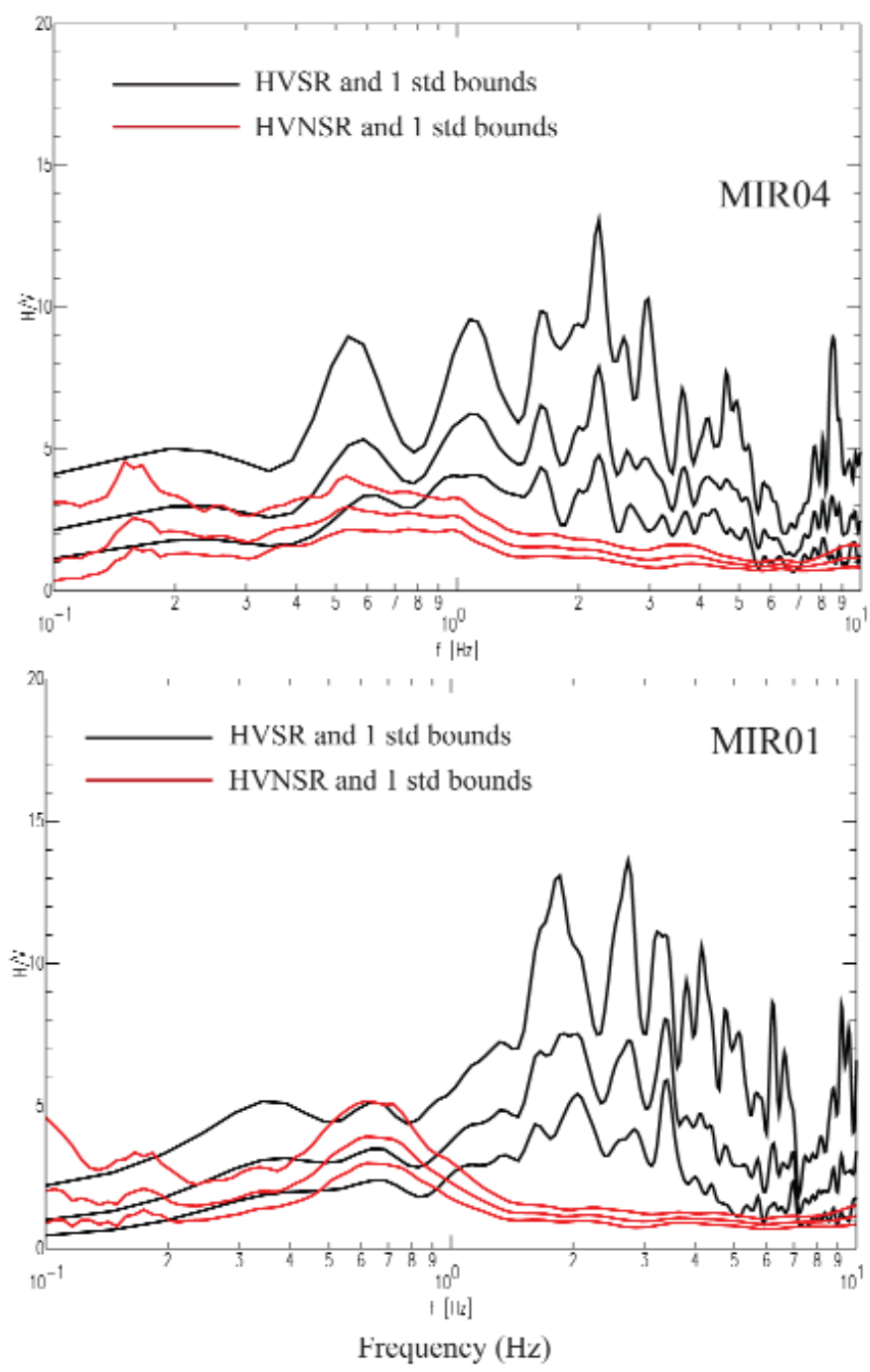

Figure 6. Comparisons between the HVSR (earthquakes, black) and HVNSR (noise, red) at two sites, MIR04 (top) and MIR01 (bottom). HVSRs are averaged over seven events (listed in Table 2). The one standard deviation boundaries are also given.

S-P time is very small), and anyway, the S-wave and surfacewave contributions are predominant. All of the analyzed sites are in the epicentral area and in a near-source condition (see Table 2 for the selected events), and therefore the differences among the sites obviously include some source effects. The only exception is the June $6,2012, M_{L} 4.5$ event from a few tens of kilometers southeast of the epicentral area.

Using continuous recording, we computed spectral ratios on ambient noise (HVNSR) [Nakamura 1989]. All of the signals were processed with a detrigger algorithm [SESAME 2004], to remove noise windows containing disturbing and transient phenomena. The single window length was set to $60 \mathrm{~s}$, to enhance the resolution in the low-frequency range. The Fourier spectra were smoothed with a Konno and Omachi [1998] algorithm, and HVNSR was evaluated on the geometrical mean of the Fourier spectra of the horizontal components.

It is generally accepted (for an overview, see Bard 1998) that the HVSNR can be used to detect the predominant pe- riod of resonance, while this generally underestimates the amplitude of amplification. For this reason, this cannot be used as the empirical transfer function of the soil.

As an example of our results, we show sites MIR04 and MIR01 (Figure 6). As often seen in the literature, the HVNSRs have a simple shape in comparison to the HVSRs. The HVSRs are characterized by broad-band amplification that includes many peaks with large amplitudes. These frequency peaks do not always agree with those detected using noise. The variations in the HVSRs among the sites is remarkable. At MIR array stations, the HVNSR frequency peak is within the range $0.6 \mathrm{~Hz}$ to $0.9 \mathrm{~Hz}$. Such a low-frequency peak is arguably linked to the thickness of the soft deposits. The HVNSR peak between $0.1 \mathrm{~Hz}$ and $0.2 \mathrm{~Hz}$, which is probably due to deeper interfaces, needs more investigation because it is on the resolution limits of the equipment used.

The data analysis has just started, therefore it is not possible to give a detailed interpretation of the described discrepancies between the earthquake and noise spectral ratios. Furthermore, we need to know the detail of the local geology better, to define correlations with the high frequency behavior of the spectral ratio. As a general comment, the differences between the spectra suggest that the HVSRs catch the complex wave-field interactions due to the subdued geology, which is excited only during earthquakes, although they obviously include some source and propagation effects. On the contrary, the HVNSR on noise can probably only catch the dominant period of resonance, which can be used to constrain the thickness of the soft sediments of the geological model using a 1D assumption, provided that the impedance contrast is strong enough to ensure the reliability of the method. For the further analysis, it will be interesting to compute the HVSR splitting the earthquakes into two datasets, as the near field and far field datasets.

\section{Future developments}

The dataset collected by EMERSITO network includes a remarkable quantity of high-quality data that spans the entire range of ground motion from microtremors to $M_{L} 5.8$, and it was also recorded under near-field conditions. This can be used in seismic-response studies and non-linear soil behavior studies, and for ground-motion prediction. This will be included in the dataset recorded by the emergency rapidresponse network of INGV, SEISMIKO [Moretti et al. 2012].

\section{Data and shared resources}

The continuous recordings will be archived into the EIDA database (http:/ / eida.rm.ingvit/), under restricted access.

Acknowledgements. The EMERSITO group is grateful to the people of Emilia-Romagna for their warm support during the deploying activities, despite the grief and the difficult times. We thank two anonymous reviewers and the Editor, who provided valuable comments and suggestions for improvements to our manuscript. 


\section{References}

Bard, P.-Y. (1998). Microtremor measurements: a tool for siteeffect estimation, in Proceedings of the 2nd International Symposium on the Effects of Surface Geology on Seismic Motion, Yokohama, Japan, 1251-1279.

Bindi, D., S. Parolai, F. Cara, G. Di Giulio, G. Ferretti, L. Luzi, G. Monachesi, F. Pacor and A. Rovelli (2009). Site amplifications observed in the Gubbio Basin, central Italy: hints for lateral propagation effects, B. Seismol. Soc. Am., 99, 741-760; doi:10.1785/ 0120080238.

Bindi, D., F. Pacor, L. Luzi, R. Puglia, M. Massa, G. Ameri and R. Paolucci (2011). Ground motion prediction equations derived from the Italian strong motion database, B. Earthq. Eng., 9, 1899-1920; doi:10.1007/s10518-011-9313.

Borcherdt, R.D. (1970). Effects of local geology on ground motion near San Francisco Bay, B. Seismol. Soc. Am., 60, 29-61.

Bordoni, P., G. Cultrera, L. Margheriti, P. Augliera, G. Caielli, M. Cattaneo, R. de Franco, A. Michelini and D. Spallarossa (2003). A microseismic study in a low seismicity area: the 2001 site-response experiment in the Città di Castello (Italy) basin, Annals of Geophysics, 46 (6), 13151324.

Cara, F., G. Di Giulio, G.P. Cavinato, D. Famiani and G. Milana (2011). Seismic characterization and monitoring of Fucino Basin (central Italy), B. Earthq. Eng., 9, 1961-1985; doi:10.1007/s10518-011-9282-2.

Cerrina Feroni, A., L. Martelli, P. Martinelli and G. Ottria, with the contributions of R. Catanzariti (2002). Carta Geologico-Strutturale dell'Appennino Emiliano-Romagnolo alla scala 1:250000, (Regione Emilia-Romagna, Servizio Geologico, Sismico e dei Suoli, CNR, Istituto di Geoscienze e Georisorse,Pisa), S.EL.CA., Firenze.

Chávez-García, F.J., W.R. Stephenson and M. Rodríguez (1999). Lateral propagation effects observed at Parkway, New Zealand. A case history to compare $1 \mathrm{D}$ versus $2 \mathrm{D}$ site effects, B. Seismol. Soc. Am., 89, 718-732.

Day, S.M., R. Graves, J. Bielak, D. Dreger, S. Larsen, K.B. Olsen, A. Pitarka and L. Ramirez-Guzmanc (2008). Model for basin effects on long-period response spectra in southern California, Earthq. Spectra, 24, 257-277.

Di Giulio, G., S. Marzorati, F. Bergamaschi, P. Bordoni, F. Cara, E. D'Alema, C. Ladina and M. Massa (2011). Local variability of the ground shaking during the 2009 L'Aquila earthquake (April 6, 2009; $\mathrm{M}_{\mathrm{W}}$ 6.3): the case study of Onna and Monticchio villages. B. Earthq. Eng., 9, 783-807; doi:10.1007/s10518-011-9243-9.

Graves, R.W., A. Pitarka, and P.G. Somerville (1998). Groundmotion amplification in the Santa Monica area: Effects of shallow basin-edge structure, B. Seismol. Soc. Am., 88, 1224-1242.

Joyner, W.B.. and D.M. Boore (1981). Peak Horizontal Acceleration and Velocity from Strong- Motion Records In- cluding Records from the 1979 Imperial Valley, California, Earthquake, B. Seismol. Soc. Am., 71 (6), 2011-2038.

Kawase, H. (1996). The cause of the damage belt in Kobe: 'the basin edge effect' constructive interference of the direct $S$-wave with the basin induced diffracted/Rayleigh waves, Seismol. Res. Lett., 67 (5), 25-34.

Konno, K., and T. Ohmachi (1998). Ground-motion characteristics estimated from spectral ratio between horizontal and vertical components of microtremor, B. Seismol. Soc. Am., 88, 228-241.

Lermo, J., and E.J. Chavez-Garcia (1993). Site effect evaluation using spectral ratios with only one station, B. Seismol. Soc. Am., 83, 1574-1594.

Margheriti, L., R. Azzara, M. Cocco, A. Delladio and A. Nardi, (2000). Analyses of borehole broadband recordings: test site in the Po basin, Northen Italy, B. Seismol. Soc. Am., 90, 1454-1463.

Margheriti, L., L. Chiaraluce, C. Voisin, G. Cultrera, A. Govoni, M. Moretti, P. Bordoni, L. Luzi, R. Azzara, L. Valoroso, R. Di Stefano, A. Mariscal, L. Improta, F. Pacor, G. Milana, M. Mucciarelli, S. Parolai, A. Amato, C. Chiarabba, P. De Gori, F. Pio Lucente, M. Di Bona, M. Pignone, G. Cecere, F. Criscuoli, A. Delladio, V. Lauciani, S. Mazza, G. Di Giulio, F. Cara, P. Augliera, M. Massa, E. D'Alema, S. Marzorati, M. Sobiesiak, A. Strollo, A.-M. Duval, P. Dominique, B. Delouis, A. Paul, S. Husen and G. Selvaggi (2011). Rapid response seismic networks in Europe: the example of L'Aquila earthquake emergency, Annals of Geophysics, 54 (4), 392-399; doi:10.4401/ag4953.

Massa, M., S. Lovati, D. Sudati, G. Franceschina, E. Russo, R. Puglia, G. Ameri, L. Luzi, F. Pacor and P. Augliera (2012). INGV strong-motion data web-portal: a focus on the Emilia seismic sequence of May-June 2012, Annals of Gephysics, 55 (4); doi:10.4401/ag-6120.

Milana, G., R.M. Azzara, E. Bertrand, P. Bordoni, F. Cara, R. Cogliano, G. Cultrera, G. Di Giulio, A.M. Duval and A. Foderella (2011). The contribution of seismic data in microzonation studies for downtown L'Aquila, B. Earthq. Eng., 9-3, 741-759; doi:10.1007/s10518-011-9246-6.

Moretti, M., L. Abruzzese, N. Abu Zeid, P. Augliera, R. Azzara, C. Barnaba, L. Benedetti, A. Bono, P. Bordoni, T. Boxberger, A. Bucci, S. Cacciaguerra, M. Calò, F. Cara, S. Carannante, V. Cardinale, A. Castagnozzi, M. Cattaneo, A. Cavaliere, G. Cecere, C. Chiarabba, L. Chia-raluce, M.G. Ciaccio, R. Cogliano, G. Colasanti, M. Colasanti, C. Cornou, F. Courboulex, F. Criscuoli, G. Cultrera, E. D'Alema, C. D'Ambrosio, S. Danesi, P. De Gori, A. Delladio, G. De Luca, M. Demartin, G. Di Giulio, C. Dorbath, E. Ercolani, L. Faenza, L. Falco, A. Fiaschi, P. Ficeli, A. Fodarella, D. Franceschi, G. Franceschina, M. Frapiccini, M. Frogneux, L. Giovani, A. Govoni, L. Improta, E. Jacques, C. Ladina, P. Langlaude, V. Lauciani, B. Lolli, S. 
Lovati, F.P. Lucente, L. Luzi, A. Mandiello, C. Marcocci, L. Margheriti, S. Marzorati, M. Massa, S. Mazza, D. Mercerat, G. Milana, F. Minichiello, G. Molli, G. Monachesi, A. Morelli, R. Moschillo, F. Pacor, D. Piccinini, U. Piccolini, M. Pignone, S. Pintore, S. Pondrelli, E. Priolo, S. Pucillo, M. Quintiliani, G. Riccio, M. Romanelli, A. Rovelli, S. Salimbeni, L. Sandri, G. Selvaggi, A. Serratore, M. Silvestri, L. Valoroso, J. Van der Woerd, G. Vannucci and L. Zaccarelli (2012). Rapid response to the earthquake emergency of May 2012 in the Po Plain, northern Italy, Annals of Geophysics, 55 (4); doi:10.4401/ag-6152.

Nakamura, Y. (1989). A method for dynamic characteristics estimation of subsurface using microtremors and the ground surface, Q. Rept. RTRI Japan, 30, 25-33

Pacor, F., R. Paolucci, G. Ameri, M. Massa and R. Puglia (2011). Italian strong motion records in ITACA: overview and record processing, B. Earthq. Eng., 9 (6), 1761-1778; doi:10.1007/s10518-011-9295-x.

Pieri, M., and G. Groppi (1981). Subsurface geological structure of the Po Plain (Italy), C.N.R., Progetto Finalizzato Geodinamica, Pubbicazione n. 414, 1-13.

Pitarka, A., K. Irikura, T. Iwata, and H. Sekiguchi (1998). Three-dimensional simulation of the nearfault ground motion for the 1995 Hyogoken Nanbu (Kobe), Japan, earthquake, B. Seismol. Soc. Am., 88, 428-440.

Regione Emilia-Romagna ENI-AGIP (1998). Riserve idriche sotterranee della Regione Emilia Romagna, G. Di Dio (ed.), S.EL.CA., Firenze, 120 pp.

Regione Emilia-Romagna (1999). Carta geologica di pianura dell'Emilia Romagna, D. Preti (ed.), S.EL.CA., Firenze.

Scognamiglio, L., L. Margheriti, F.M. Mele, E. Tinti, A. Bono, P. De Gori, V. Lauciani, F.P. Lucente, A.G. Mandiello, C. Marcocci, S. Mazza, S. Pintore and M. Quintiliani (2012). The 2012 Pianura Padana Emiliana seimic sequence: locations, moment tensors and magnitudes, Annals of Geophysics, 55 (4); doi:10.4401/ag-6159.

SESAME (2004). Guidelines for the implementation of the $\mathrm{H} / \mathrm{V}$ spectral ratio technique on ambient vibrations-measurements, processing and interpretations. SESAME European research project EVG1-CT-2000-00026, deliverable D23.12, http: / / sesame-fp5.obs.ujfgrenoble.fr/

Tertulliani, A., L. Arcoraci, M. Berardi, F. Bernardini, B. Brizuela, C. Castellano, S. Del Mese, E. Ercolani, L. Graziani, A. Maramai, A. Rossi, M. Sbarra and M. Vecchi (2012). The Emilia 2012 sequence: a macroseismic survey, Annals of Geophysics, 55 (4); doi:10.4401/ag-6140.

\footnotetext{
${ }^{\star}$ Corresponding author: Paola Bordoni, Istituto Nazionale di Geofisica e Vulcanologia, Centro Nazionale Terremoti, Roma, Italy; email: paola.bordoni@ingv.it. 